\title{
ANALISIS USAHA PEMANFAATAN KULIT BUAH KAKAO (Theobrama Cacao L.) FERMENTASI DENGAN CAIRAN RUMEN TERHADAP SAPI PERANAKAN ONGOLE (PO)
}

\author{
(Economy Analysis of fermented cacao pod (Cacao Theobrama L.) by Rumen Fluid on the \\ Ongole crossbred cattle fattening)
}

Surya Winarto, Sayed Umar dan Iskandar Sembiring

Program Studi Peternakan Fakultas Pertanian Universitas Sumatera Utara

\begin{abstract}
The research was conducted in Biology Laboratory of agricultural faculty. University of Sumatera Utara, Medan from October 2011 until January 2012. The objective of study is to investigate economic anaysis of fermented cacao pod (Theobrama cacao L.) by rumen fluid on ongole crossbred cattle fattening. Methodology used Latin Square Design with 4 treatments. Treatments are $\mathrm{P}_{0}\left(0 \%\right.$ of fermented pod cacao), $\mathrm{P}_{1}(10 \%$ of fermented pod cacao), $\mathrm{P}_{2}$ (20\% of fermented pod cacao), $\mathrm{P}_{3}$ (30\% of fermented pod cacao). The results showed that on average profit / loss the was at highest at $\mathrm{P}_{0}$ of Rp. 527 405,- and the lowest was on $\mathrm{P}_{3}$ of Rp. 426 786,-. Average benefit cost ratio $(\mathrm{B} / \mathrm{C})$ was highest at $\mathrm{P}_{0}$ of 1.10 , and 1.07 for the smallest at $\mathrm{P}_{3}$. Average Break Event Point (BEP) BEP which consist of the highest production rates was on $\mathrm{P}_{3}$ of Rp. 23375 ,- as the highest and the lowest at $\mathrm{P}_{0}$ of Rp. 23016 ,Average BEP highest production volume was of $239 \mathrm{~kg}$ on $\mathrm{P}_{2}$ and $\mathrm{P}_{0}$ for the smallest at $234 \mathrm{~kg}$. The highest income over feed cost (IOFC) was highest at $\mathrm{P}_{0} \mathrm{Rp} .597$ 718, $\mathrm{P}_{3}$ and lowest at Rp. 476 339, -. The highest Average return on investment (ROI) of $11.80 \%$ at $\mathrm{P}_{0}$, and the smallest at $7.94 \%$ in $\mathrm{P}_{3}$. It is concluded that the utilization of fermented cacao pod with rumen fluid give benefits and could be used for the cattle business.
\end{abstract}

Keywords: Economic Analysis, cacao pod, Fermentation, Rumen Fluid, Ongole crossbred cattle

\begin{abstract}
ABSTRAK
Kulit buah kakao fermentasi dengan cairan rumen mempunyai kandungan nutrisi yang baik dan harganya relatif murah dan berpotensi sebagai bahan pakan yang ekonomis sehingga dapat mengefisiensi biaya pakan dan dapat meningkatkan pendapatan. Penelitian ini dilaksanakan di laboratorium Biologi Ternak Fakultas Pertanian Universitas Sumatera Utara, Medan yang dilaksanakan pada bulan Oktober 2011 sampai Januari 2012. Penelitian ini bertujuan untuk mengetahui nilai usaha dari Pemanfaatan Kulit Buah Kakao (Theobrama Cacao L.) Fermentasi Dengan Cairan Rumen Terhadap Sapi Peranakan Ongole (PO). Metode penelitian yang digunakan adalah Rancangan Bujur Sangkar Latin dengan 4 perlakuan. Perlakuannya adalah $\mathrm{P}_{0}\left(0 \%\right.$ kulit buah kakao fermentasi), $\mathrm{P}_{1}$ (10\% kulit buah kakao fermentasi), $\mathrm{P}_{2}\left(20 \%\right.$ kulit buah kakao fermentasi), $\mathrm{P}_{3}(30 \%$ kulit buah kakao fermentasi). Hasil penelitian menunjukkan bahwa rataan laba/rugi tertinggi adalah pada $\mathrm{P}_{0}$ sebesar Rp. 527.405,- dan terkecil pada $\mathrm{P}_{3}$ sebesar Rp. 426.786,-. Rataan benefit cost ratio $(\mathrm{B} / \mathrm{C})$ tertinggi adalah pada $\mathrm{P}_{0}$ sebesar 1.10 , dan terkecil pada $\mathrm{P}_{3}$ sebesar 1,07. Rataan Break event Point (BEP) yang terdiri dari BEP harga produksi tertinggi pada $\mathrm{P}_{3}$ sebesar Rp. 23.375,- dan terkecil pada $\mathrm{P}_{0}$ sebesar Rp. 23.016,-. Rataan BEP volume produksi tertinggi pada $\mathrm{P}_{2}$ sebesar 239 $\mathrm{kg}$, dan terkecil pada $\mathrm{P}_{0}$ sebesar $234 \mathrm{~kg}$. Rataan income over feed cost (IOFC) tertinggi adalah pada $\mathrm{P}_{0}$ sebesar Rp.597.718,- dan terendah pada $\mathrm{P}_{3}$ sebesar Rp. 476.339,-. Rataan return on investment (ROI) tertinggi pada $\mathrm{P}_{0}$ sebesar $11.80 \%$, dan terkecil pada $\mathrm{P}_{3}$ sebesar 7,94\%. Kesimpulannya adalah pemanfaatan kulit buah kakao fermentasi dengan cairan rumen yang diberikan pada sapi peranakan ongole jantan memberikan keuntungan dan dapat digunakan dalam usaha peternakan sapi.
\end{abstract}

Kata kunci: Analisis Usaha, kulit Buah Kakao, Fermentasi, Cairan Rumen, sapi Peranakan Ongole 


\section{PENDAHULUAN}

Pembangunan sub-sektor peternakan merupakan bagian dari pembangunan sektor pertanian, dimana sub-sektor peternakan memiliki peran strategis dalam memenuhi kebutuhan protein hewani. Kebutuhan protein hewani terus meningkat sejalan dengan pertambahan penduduk dan peningkatan taraf hidup serta kesadaran gizi bagi masyarakat. Keberhasilan pembangunan ternyata berdampak pada perubahan konsumsi masyarakat yang semula lebih banyak mengkonsumsi karbohidrat beralih kearah konsumsi protein seperti daging, telur, dan susu. Akan tetapi ketersediaan produksi daging masih rendah. Dalam upaya meningkatkan produksi daging, pemerintah Indonesia telah dua kali gagal mencapai target swasembada daging sapi yakni pecanangan pada 2005 dan 2010. Kini, pemerintah kembali mencanangkan program kecukupan daging pada 2014.

Kendala utama produksi daging di dalam negeri justru disebabkan populasi sapi lokal yang cenderung terus menurun dan mengakibatkan produksi daging masih rendah, sehingga tidak dapat memenuhi kebutuhan di dalam negeri. Salah satu indikator produksi daging rendah diakibatkan permintaan daging yang meningkat sedangkan persediaan sapi potong jantan kurang sehingga sapi betina produktif pun ikut dipotong. Produktivitas yang rendah merupakan kendala peningkatan produksi daging terutama pada usaha sapi potong rakyat, disamping itu juga keterbatasan modal, kurang berwawasan agribisnis serta tatalaksana pemeliharaan yang masih tradisional. sehingga tingkat pertambahan bobot badan dibawah $0,5 \mathrm{~kg} / \mathrm{hari}$.

Pakan merupakan faktor penting dalam usaha peternakan, nutrisi yang seimbang dan cukup akan menghasilkan produksi daging yang tinggi. Akan tetapi kualitas pakan yang rendah akan menyebabkan produksi sapi rendah. Salah satu cara untuk mengatasinya adalah dengan memperbaiki kualitas pakan, namun pakan komersil yang berkualitas harganya relatif mahal, disamping itu penggunaan pakan komersil akan menambah pendapatan dari usaha penggemukan tersebut. Maka untuk itu perlu dicari bahan pakan yang relatif murah dan mengandung nilai nutrisi yang baik serta mudah diperoleh.

Kemajuan dan perkembangan ilmu pengetahuan di bidang peternakan mengubah pola pikir, untuk memanfaatkan hasil samping limbah pertanian dan perkebunan menjadi pakan ternak yang bermutu tinggi dan ekonomis. Bahan pakan ternak berbasis limbah kakao sebagai bahan pakan inkonvensional yang kompetitif. Akan tetapi, kulit buah kakao mempunyai 
kelemahan yakni memiliki kandungan serat kasar yang tinggi dan terdapat zat anti nutrisi yang mengakibatkan nilai nutrisi kulit buah kakao rendah.

Cara untuk meningkatkan nilai nutrisi dan kecernaan kulit buah kakao serta aman penggunaannya adalah dengan cara biologis yaitu dengan teknik fermentasi dengan menggunakan cairan rumen sapi yang bertujuan untuk mendegradasi lignin yang ada dalam pakan tersebut, sehingga dapat diberikan kepada ternak selama periode penggemukan. Mikroorganisme rumen yang terdapat di dalam retikulo rumen mempunyai peran penting dalam proses fermentasi pakan (Tri Akoso,1996). Diantara bakteri-bakteri tersebut termasuk di dalamnya bakteri yang dapat mencerna serat kasar yaitu bakteri selulolitik (Arora, 1989).

Berdasarkan uraian diatas maka penulis tertarik untuk mengetahui sejauh mana nilai ekonomis pemberian limbah perkebunan kakao yang difermentasi dengan cairan rumen dalam pakan terhadap pertumbuhan bobot badan sapi Peranakan Ongole (PO) dengan melakukan penelitian analisa ekonomi pemanfaatan kulit buah kakao (Theobrama Cacao L.) fermentasi dengan cairan rumen dalam pakan terhadap sapi peranakan ongole (PO).

\title{
BAHAN DAN METODE
}

\section{Tempat dan Waktu Penelitian}

Penelitian ini dilaksanakan di Laboratorium Biologi Ternak, Program Studi Peternakan, Fakultas Pertanian, Universitas Sumatera Utara, Medan. Penelitian ini dilaksanakan selama 4 bulan yang dimulai pada bulan Oktober 2011 sampai Januari 2012.

\section{Bahan}

Bahan yang digunakan dalam penelitian ini adalah 4 ekor sapi peranakan ongole jantan lepas sapih (umur 10 - 18 bulan), hijauan lapangan, konsentrat yang terdiri atas: kulit buah kakao fermentasi, dedak padi, tongkol jagung, solid dekanter, bungkil inti sawit, molasses, urea, kapur, garam dan ultra mineral, obat-obatan dan air minum.

\begin{abstract}
Alat
Alat yang digunakan dalam penelitian ini adalah kandang individu sebanyak 4 unit beserta perlengkapannya, tempat pakan dan minum, timbangan untuk menimbang berat badan sapi selama penelitian, timbangan dengan kapasitas $2 \mathrm{~kg}$ dengan kepekaan $10 \mathrm{~g}$ untuk
\end{abstract}


menimbang konsentrat, timbangan dengan kapasitas $10 \mathrm{~kg}$ dengan kepekaan $10 \mathrm{~g}$ untuk menimbang hijauan, kandang jepit yang digunakan pada saat penimbangan bobot badan sapi dilaksanakan, alat kebersihan (ember, sapu, pisau, sabit, tempat sampah), lampu sebagai alat penerangan, kalkulator sebagai alat untuk mempermudah perhitungan, dan alat tulis sebagai alat pencatat data selama penelitian

\section{Metode Penelitian}

Rancangan penelitian yang digunakan dalam penelitian adalah rancangan bujur sangkar latin 4 perlakuan x 4 ulangan. Perlakuan yang diteliti adalah :

$\mathrm{P}_{0}=$ Hijauan Lapangan + konsentrat tanpa kulit buah kakao

$\mathrm{P}_{1}=$ Hijauan Lapangan + konsentrat dengan Kulit Buah Kakao fermentasi 10\%

$\mathrm{P}_{2}=$ Hijauan Lapangan + konsentrat dengan Kulit Buah Kakao fermentasi 20\%

$\mathrm{P}_{3}=$ Hijauan Lapangan + konsentrat dengan Kulit Buah Kakao fermentasi 30\%

Model matematika yang digunakan Sastrosupadi (2000) adalah

\section{Dimana :}

$$
\mathbf{Y}_{i j k}=\boldsymbol{\mu}+\mathbf{T}_{j}+\mathbf{B} \boldsymbol{j}+\mathbf{K}_{k}+\mathbf{\epsilon}_{i j k}
$$

$\mathrm{Y}_{i j k}=\quad$ Hasil pengamatan dari perlakuan ke-i, baris ke-j dan kolom ke-k

$\mathrm{T}_{i}=\quad$ Pengaruh perlakuan ke-i

$\mathrm{B}_{j}=\quad$ Pengaruh baris ke- $\mathrm{j}$

$\mathrm{K}_{k}=$ Pengaruh kolom ke-k

$\mu=$ Nilai tengah umum

$\epsilon_{i j k}=$ Pengaruh galat karena perlakuan ke-i, baris ke-j dan kolom ke- $\mathrm{k}$

\section{Peubah Penelitian}

\section{Analisis Usaha}

\section{Total Biaya Produksi}

Total biaya produksi atau total pengeluaran yaitu biaya-biaya yang dikeluarkan untuk menghasilkan suatu produk, diperoleh dengan cara menghitung : Biaya pembelian bibit, Sewa kandang dan peralatan, Biaya pakan, Biaya obat-obatan, dan Biaya tenaga kerja.

\section{Total Hasil Produksi}

Total hasil produksi atau total penerimaan yaitu seluruh produk yang dihasilkan dalam kegiatan ekonomi diperoleh dengan cara menghitung : Harga jual sapi, dan Harga jual kotoran sapi. 


\section{Analisa Laba-Rugi}

Analisa ekonomi atau Laba-Rugi dilakukan untuk mengetahui apakah usaha tersebut menguntungkan atau rugi dengan cara menghitung selisih antara total penerimaan (total reserve) dengan total pengeluaran (total cost).

\section{Benefit Cost Ratio (B/C Ratio)}

B/C Ratio dilakukan untuk mengetahui tingkat efisiensi suatu usaha yaitu dengan cara membagikan total pendapatan dengan total biaya produksi.

\section{Income Over Feed Cost (IOFC)}

IOFC didapat dengan cara pendapatan usaha peternakan yang didapat dari berat badan ternak (bobot potong-bobot awal) di kali harga ternak/Kg dikurangi dengan biaya pakan (total konsumsi dikali harga pakan).

\section{Break Even Point (BEP)}

BEP dilakukan untuk mencari titik impas atau pulang modal dari suatu usaha. BEP didasarkan atas volume produksi yang menggambarkan produksi minimal yang harus dihasilkan agar usaha ini tidak mengalami kerugian dengan cara membagikan total biaya produksi (Rp) dengan harga produksi di tingkat petani $(\mathrm{Rp} / \mathrm{kg})$ dan harga produksi yang menggambarkan harga terendah dari produksi yang dihasilkan dengan cara membagikan total biaya produksi dengan total produksi.

\section{Return on Investment (ROI)}

Di dapat dengan cara membagikan pendapatan bersih dari usaha (Net Income) dengan total modal usaha (Total Asset) dan dikalikan dengan 100\%.

\section{Pengambilan data dan analisis data}

Langkah-langkah pengambilan data dan analisa data:

1. Dilakukan pengukuran (pretest) yaitu data rata-rata bobot badan awal sapi pada setiap level perlakuan pakan. 
2. Dilakukan survey harga pakan yaitu diarea pasar, poultry shop, pabrik pakan ternak dan tempat-tempat lain yang menyangkut harga pakan dan harga peralatan-peralatan yang digunakan.

3. Dilakukan pengukuran (posttest) yaitu data dari hasil variable penelitian yang terdiri dari bobot badan awal sapi dan bobot akhir sapi dan rata-rata konsumsi pakan sapi pada setiap level perlakuan pakan.

Dilakukan analisis ekonomi pada data-data pretest dan posttest untuk mengetahui nilai ekonomis dari keseluruhan usaha ternak sapi. Analisis ekonomi yang dilihat adalah analisis laba rugi, analisis $\mathrm{B} / \mathrm{C}$ ratio, analisis $\mathrm{BEP}$, analisis IOFC dan analisis $\mathrm{ROI}$.

\section{HASIL DAN PEMBAHASAN}

\section{Analisis Usaha}

\section{Total Biaya Produksi}

Total biaya produksi atau total pengeluaran yaitu biaya-biaya yang dikeluarkan untuk menghasilkan suatu produk, diperoleh dengan cara menghitung: biaya pembelian sapi, biaya pakan, biaya sewa kandang, biaya peralatan, biaya obat-obatan dan biaya tenaga kerja.

\section{a. Biaya Bibit}

Biaya bibit yaitu biaya yang dikeluarkan untuk membeli bibit sapi sebanyak 4 ekor. Harga diperoleh dari hasil perkalian antara bobot badan awal dengan harga bobot hidup perkilogramnya. Harga bobot hidup perkilogram yang digunakan adalah Rp. 25.000,- sehingga diperoleh biaya bibit seperti tertera pada Tabel 1.

\section{b. Biaya Pakan}

Biaya yang dikeluarkan untuk membeli pakan yang diperoleh dari perkalian antara jumlah pakan yang dikonsumsi dengan harga pakan perkilogramnya sehingga diperoleh biaya pakan yang dikonsumsi selama penelitian seperti yang tertera pada Tabel 2.

\section{a. Biaya/Upah tenaga kerja}

Biaya atau upah tenaga kerja adalah biaya yang dikeluarkan untuk memelihara sapi selama penelitian. Berdasarkan UMRP SUMUT 2012 (Upah Minimum Regional Propinsi Sumatera) sebesar Rp. 1.200.000/bulan. Dengan asumsi 1 orang tenaga kerja dapat menangani 
20 ekor sapi. Sehingga biaya yang dikeluarkan untuk 4 ekor sapi sebesar Rp. 240.000/bulan yang berarti biaya yang dikeluarkan selama penelitian (4 bulan) sebesar Rp 960.000,-.

Tabel 1. Harga bibit sapi tiap perlakuan selama penelitian $(\mathrm{Rp})$

\begin{tabular}{|c|c|c|c|c|c|c|}
\hline \multirow{2}{*}{ Perlakuan } & \multicolumn{4}{|c|}{ Ulangan } & \multirow{2}{*}{ Total } & \multirow{2}{*}{ Rataan } \\
\hline & S1 & S2 & S3 & S4 & & \\
\hline P0 & 4.200 .000 & 4.875 .000 & 6.100 .000 & 6.275 .000 & 21.450 .000 & 5.362 .500 \\
\hline P1 & 5.350 .000 & 4.025 .000 & 5.400 .000 & 7.450 .000 & 22.225 .000 & 5.556 .250 \\
\hline P2 & 7.075 .000 & 5.675 .000 & 3.925 .000 & 5.300 .000 & 21.975 .000 & 5.493 .750 \\
\hline P3 & 6.375 .000 & 6.700 .000 & 4.700 .000 & 4.150 .000 & 21.925 .000 & 5.481 .250 \\
\hline
\end{tabular}

Tabel 2. Biaya pakan tiap perlakuan selama penelitian ( $\mathrm{Rp})$

\begin{tabular}{|c|c|c|c|c|c|c|}
\hline \multirow{2}{*}{ Perlakuan } & \multicolumn{4}{|c|}{ Ulangan } & \multirow{2}{*}{ Total } & \multirow{2}{*}{ Rataan } \\
\hline & S1 & $\mathrm{S} 2$ & S3 & $\mathrm{S} 4$ & & \\
\hline P0 & 314.644 & 305.229 & 440.317 & 398.870 & 1.459 .060 & 364.765 \\
\hline $\mathrm{P} 1$ & 356.926 & 278.462 & 325.310 & 494.196 & 1.454 .894 & 363.724 \\
\hline $\mathrm{P} 2$ & 473.965 & 352.017 & 270.366 & 348.918 & 1.445 .266 & 361.317 \\
\hline $\mathrm{P} 3$ & 400.991 & 445.631 & 309.462 & 313.562 & 1.469 .646 & 367.412 \\
\hline
\end{tabular}

\section{b. Biaya Sewa Kandang}

Biaya yang dikeluarkan untuk pengadaan kandang diperhitungkan berdasarkan nilai sewa kandang sehingga diperoleh sewa kandang selama penelitian. Biaya yang dikeluarkan untuk pengadaan kandang selama penelitian sebesar Rp.750.000,- sehingga biaya yang dikeluarkan untuk 4 ekor sapi dengan masa pemeliharaan selama 4 bulan sebesar Rp. 46.875 .

\section{c. Biaya Obat-obatan}

Selama penelitian, obat-obatan yang digunakan adalah vitamin B-kompleks ${ }^{\circledR}$ dan obat cacing wormzolk-B ${ }^{\circledR}$ dengan harga per 10cc sebesar Rp 1.000 untuk vitamin B-kompleks ${ }^{\circledR}$ dan Rp. 3.500.- untuk obat cacing wormzolk-B®. sehingga diperoleh biaya per ekor sebesar Rp. 4.500 . 


\section{Total Hasil Produksi}

Total hasil produksi atau total penerimaan yaitu seluruh produk yang dihasilkan dalam kegiatan pemeliharaan sapi ini yang diperoleh dengan cara menhitung harga jual sapi beserta feses.

Dari keseluruhan biaya diatas, maka data total biaya produksi yang diperoleh seperti yang tertera pada Tabel 3 .

Tabel 3. Total biaya produksi tiap perlakuan selama penelitian ( $\mathrm{Rp})$

\begin{tabular}{|c|c|c|c|c|c|c|}
\hline \multirow{2}{*}{ Perlakuan } & \multicolumn{3}{|c|}{ Ulangan } & \multirow[b]{2}{*}{ S4 } & \multirow{2}{*}{ Total } & \multirow{2}{*}{ Rataan $^{\text {tn }}$} \\
\hline & S1 & S2 & S3 & & & \\
\hline P0 & 4.626 .019 & 5.291 .604 & 6.785 .245 & 6.651 .692 & 23.354 .560 & 5.838 .640 \\
\hline P1 & 4.414 .837 & 5.818 .301 & 5.836 .685 & 8.055 .571 & 24.125 .394 & 6.031 .349 \\
\hline $\mathrm{P} 2$ & 4.306 .741 & 5.760 .293 & 6.138 .392 & 7.660 .340 & 23.865 .766 & 5.966 .442 \\
\hline P3 & 4.574 .937 & 5.120 .837 & 6.887 .366 & 7.257 .006 & 23.840 .146 & 5.960 .037 \\
\hline
\end{tabular}

keterangan : tn ; tidak berbeda nyata

\section{a. Penjualan Sapi}

Penjualan sapi yaitu hasil perkalian antara bobot badan akhir dengan harga bobot hidup perkilogramnya. Harga bobot hidup perkilogram yang digunakan sebesar Rp. 25.000,- sehingga diperoleh hasil penjualan sapi selama penelitian tertera pada tabel 4 .

Tabel 4. Harga jual sapi tiap perlakuan selama penelitian. (Rp)

\begin{tabular}{|c|c|c|c|c|c|c|}
\hline \multirow{2}{*}{ Perlakuan } & \multicolumn{3}{|c|}{ Ulangan } & & \multirow{2}{*}{ Total } & \multirow{2}{*}{ Rataan } \\
\hline & $\mathrm{S} 1$ & S2 & S3 & S4 & & \\
\hline P0 & 5.350 .000 & 5.675 .000 & 6.825 .000 & 7.450 .000 & 25.300 .000 & 6.325 .000 \\
\hline P1 & 6.375 .000 & 4.875 .000 & 6.100 .000 & 8.550 .000 & 25.900 .000 & 6.475 .000 \\
\hline $\mathrm{P} 2$ & 8.000 .000 & 6.700 .000 & 4.700 .000 & 6.275 .000 & 25.675 .000 & 6.418 .750 \\
\hline P3 & 7.075 .000 & 7.600 .000 & 5.400 .000 & 5.300 .000 & 25.375 .000 & 6.343 .750 \\
\hline
\end{tabular}

\section{b. Penjualan Kotoran Sapi}

Yaitu hasil perkalian antara jumlah feses dengan harga perkilogramnya, harga kotoran basah perkilogram yang digunakan adalah Rp. 100,- sehingga diperoleh hasil penjualan kotoran sapi seperti yang tertera pada Tabel 5.Dari keseluruhan biaya diatas, maka data total hasil produksi yang diperoleh seperti yang tertera pada tabel 6 . 


\section{Analisis Keuntungan (Laba/Rugi)}

Keuntungan (laba) dan rugi suatu usaha diketahui setelah total hasil produksi dikurangi dengan total biaya produksi. Sehingga diperoleh keuntungan (laba) seperti yang tertera pada tabel 7.

Tabel 5. Harga penjualan kotoran sapi/ perlakuan (Rp)

\begin{tabular}{|c|c|c|c|c|c|c|}
\hline \multirow{2}{*}{ Perlakuan } & \multicolumn{4}{|c|}{ Ulangan } & \multirow{2}{*}{ Total } & \multirow{2}{*}{ Rataan } \\
\hline & S1 & $\mathrm{S} 2$ & S3 & S4 & & \\
\hline P0 & 41.100 & 36.900 & 39.020 & 47.160 & 164.180 & 41.045 \\
\hline P1 & 37.500 & 41.160 & 38.100 & 50.160 & 166.920 & 41.730 \\
\hline $\mathrm{P} 2$ & 49.300 & 42.900 & 36.600 & 45.690 & 174.490 & 43.623 \\
\hline P3 & 44.100 & 45.000 & 36.690 & 46.500 & 172.290 & 43.073 \\
\hline
\end{tabular}

Tabel 6. Biaya total hasil produksi selama penelitian $(\mathrm{Rp})$

\begin{tabular}{lllllll}
\hline \multirow{2}{*}{ Perlakuan } & \multicolumn{5}{c}{ Ulangan } & \multicolumn{2}{c}{ Total } & \multirow{2}{*}{ Rataan $^{\text {tn }}$} \\
\cline { 2 - 5 } & S1 & S2 & S3 & S4 & & \\
\hline P0 & 5.391 .100 & 5.711 .900 & 6.864 .020 & 7.497 .160 & 25.464 .180 & 6.366 .045 \\
P1 & 6.412 .500 & 4.916 .160 & 6.138 .100 & 8.600 .160 & 26.066 .920 & 6.516 .730 \\
P2 & 8.049 .300 & 6.742 .900 & 4.736 .600 & 6.320 .690 & 25.849 .490 & 6.462 .373 \\
P3 & 7.119 .100 & 7.645 .000 & 5.436 .690 & 5.346 .500 & 25.547 .290 & 6.386 .823 \\
\hline
\end{tabular}

keterangan : tn ; tidak berbeda nyata

Tabel 7. keuntungan (laba-rugi) tiap level perlakuan selama penelitian (Rp)

\begin{tabular}{lllllll}
\hline \multirow{2}{*}{ Perlakuan } & \multicolumn{3}{c}{ Ulangan } & & \multirow{2}{*}{ Total } & Rataan $^{\text {th }}$ \\
\cline { 2 - 6 } & S1 & S2 & S3 & S4 & & \\
\hline P0 & 765.081 & 420.296 & 212.328 & 711.915 & 2.109 .620 & 527.405 \\
P1 & 597.859 & 497.663 & 301.415 & 544.589 & 1.941 .526 & 485.382 \\
P2 & 388.960 & 604.508 & 429.859 & 560.397 & 1.983 .724 & 495.931 \\
P3 & 231.734 & 387.994 & 315.853 & 771.563 & 1.707 .144 & 426.786 \\
\hline
\end{tabular}

keterangan : tn ; tidak berbeda nyata

\section{Analisis Benefit/Cost Ratio (B/C Ratio)}

Analisis B/C Ratio digunakan dalam suatu usaha untuk mengetahui layak atau tidaknya usaha tersebut untuk ke periode berikutnya atau sebaliknya usaha tersebut dihentikan saja karena kurang layak. Nilai B/C ratio dapat dilihat pada Tabel 8 . 
Tabel 8. B/C ratio tiap perlakuan selama peneilitan.

\begin{tabular}{|c|c|c|c|c|c|c|}
\hline \multirow{2}{*}{ Perlakuan } & \multicolumn{4}{|c|}{ Ulangan } & \multirow{2}{*}{ Total } & \multirow{2}{*}{ Rataan $^{\text {tn }}$} \\
\hline & S1 & $\mathrm{S} 2$ & S3 & S4 & & \\
\hline P0 & 1.17 & 1.08 & 1.03 & 1.10 & 4.38 & 1.10 \\
\hline P1 & 1.10 & 1.11 & 1.05 & 1.07 & 4.33 & 1.08 \\
\hline $\mathrm{P} 2$ & 1.05 & 1.10 & 1.10 & 1.10 & 4.35 & 1.09 \\
\hline P3 & 1.03 & 1.05 & 1.06 & 1.17 & 4.31 & 1.07 \\
\hline
\end{tabular}

keterangan : tn ; tidak berbeda nyata

\section{Break Event Point (BEP)}

Break Event Point (BEP) yaitu kondisi dimana suatu usaha dinyatakan tidak untung dan tidak rugi dan disebut titik impas. BEP (Break Event Point) dapat dibagi menjadi dua yaitu:

\section{a. BEP Harga Produksi}

Dimana diperoleh dari hasil pembagian total biaya produksi dengan berat hidup sapi $(\mathrm{kg})$.

Tabel 9. BEP harga produksi tiap perlakuan selama penelitian $(\mathrm{Rp})$

\begin{tabular}{|c|c|c|c|c|c|c|}
\hline \multirow{2}{*}{ Perlakuan } & \multicolumn{3}{|c|}{ Ulangan } & \multirow[b]{2}{*}{$\mathrm{S} 4$} & \multirow{2}{*}{-Total } & \multirow{2}{*}{ Rataan $^{\text {tn }}$} \\
\hline & S1 & S2 & S3 & & & \\
\hline P0 & 21.617 & 23.311 & 24.365 & 22.769 & 92.062 & 23.016 \\
\hline $\mathrm{P} 1$ & 22.817 & 22.640 & 23.921 & 23.554 & 92.932 & 23.233 \\
\hline $\mathrm{P} 2$ & 23.939 & 22.904 & 22.908 & 22.949 & 92.700 & 23.175 \\
\hline P3 & 24.337 & 23.872 & 23.708 & 21.580 & 93.497 & 23.374 \\
\hline
\end{tabular}

keterangan : tn ; tidak berbeda nyata

\section{b. BEP Volume Produksi}

Dimana diperoleh dari hasil pembagian total biaya produksi dengan harga penjualan perkilogram. BEP volume produksi setiap perlakuan dapat dilihat pada Tabel 10.

\section{IOFC ( Income Over Feed Cost )}

Dimana diperoleh dari hasil selisih penjualan sapi dengan biaya pakan yang digunakan selama penelitian. IOFC tiap perlakuan dapat dilihat pada Tabel 11.

Tabel 10. BEP volume produksi tiap perlakuan selama penelitian $(\mathrm{kg})$

\begin{tabular}{lllllll}
\hline \multirow{2}{*}{ Perlakuan } & \multicolumn{5}{c}{ Ulangan } & \multicolumn{2}{c}{ Total } & Rataan $^{\text {tn }}$ \\
\cline { 2 - 6 } & S1 & S2 & S3 & S4 & & 234 \\
P0 & 185 & 212 & 266 & 271 & 934 & 241 \\
P1 & 233 & 177 & 233 & 322 & 965 & 239 \\
P2 & 306 & 246 & 172 & 230 & 954 & 238 \\
P3 & 275 & 290 & 183 & 205 & 953 & \\
\hline
\end{tabular}

keterangan : tn ; tidak berbeda nyata 
Tabel 11. IOFC tiap perlakuan selama penelitian (Rp)

\begin{tabular}{|c|c|c|c|c|c|c|}
\hline \multirow{2}{*}{ Perlakuan } & \multicolumn{3}{|c|}{ Ulangan } & \multirow[b]{2}{*}{ S4 } & \multirow{2}{*}{ Total } & \multirow{2}{*}{ Rataan $^{\text {tn }}$} \\
\hline & S1 & $\mathrm{S} 2$ & S3 & & & \\
\hline P0 & 835.356 & 494.701 & 284.683 & 776.130 & 2.390 .870 & 597.718 \\
\hline $\mathrm{P} 1$ & 668.074 & 571.538 & 374.690 & 605.804 & 2.220 .106 & 555.027 \\
\hline $\mathrm{P} 2$ & 501.038 & 672.983 & 504.634 & 636.082 & 2.314 .737 & 578.684 \\
\hline $\mathrm{P} 3$ & 299.009 & 454.369 & 390.538 & 761.438 & 1.905 .354 & 476.339 \\
\hline
\end{tabular}

keterangan : tn ; tidak berbeda nyata

\section{ROI (Return on Investment)}

ROI bertujuan untuk mengetahui tingkat pengembalian modal yang ditanamkan dengan membandingkan nilai keuntungan usaha dengan modal usaha yang dikeluarkan. Dari hasil penelitian diperoleh nilai ROI pada tabel 12 .

Tabel 12. ROI tiap perlakuan selama penelitian (\%)

\begin{tabular}{|c|c|c|c|c|c|c|}
\hline \multirow{2}{*}{ Perlakuan } & \multicolumn{4}{|c|}{ Ulangan } & \multirow{2}{*}{-Total } & \multirow{2}{*}{ Rataan $^{\text {tn }}$} \\
\hline & S1 & $\mathrm{S} 2$ & S3 & $\mathrm{S} 4$ & & \\
\hline P0 & 16.54 & 7.94 & 12.21 & 10.49 & 47.18 & 11.80 \\
\hline P1 & 10.28 & 11.27 & 5.16 & 6.76 & 33.47 & 8.37 \\
\hline $\mathrm{P} 2$ & 5.08 & 9.85 & 9.98 & 9.73 & 34.64 & 8.66 \\
\hline P3 & 3.36 & 5.35 & 6.17 & 16.86 & 31.74 & 7.94 \\
\hline
\end{tabular}

keterangan : tn ; tidak berbeda nyata

Dari hasil rekapitulasi diatas dapat dilihat bahwa perlakuan $\mathrm{P}_{0}$ memberikan keuntungan rata-rata sebesar Rp. 527.405,- perlakuan $\mathrm{P}_{1}$ memberikan keuntungan Rp. 485.382,- perlakuan $\mathrm{P}_{2}$ memberikan keuntungan Rp. 495.931,- dan perlakuan $\mathrm{P}_{3}$ memberikan keuntungan Rp. 426.786,-Didapat bahwa rataan keuntungan terbesar adalah pada perlakuan $\mathrm{P}_{0}$ memberikan keuntungan sebesar Rp. 527.405,- dan terkecil pada perlakuan $\mathrm{P}_{3}$ dengan menberikan keuntungan sebesar Rp. 426.786,- . hal ini disebabkan karena pertambahan bobot badan pada perlakuan $\mathrm{P}_{0}$ lebih tinggi dari pada pertambahan bobobt badan perlakuan $\mathrm{P}_{1}, \mathrm{P}_{2}$ dan $\mathrm{P}_{3}$ sehingga harga jual tinggi dan meningkatkan pendapatan. Hal ini sesuai dengan pernyataan murtidjo (1995) bahwa Keuntungan dapat dicapai jika jumlah pendapatan yang diperoleh dari usaha tersebut lebih besar dari pada jumlah pengeluarannya. Bila keuntungan dari suatu usaha semakin meningkat, maka secara ekonomis usaha tersebut layak dipertahankan atau ditingkatkan. 
Nilai benefit cost ratio pada perlakuan $\mathrm{P}_{0}$ sebesar 1.10 , perlakuan $\mathrm{P}_{1}$ sebesar 1.08 , perlakuan $\mathrm{P}_{2}$ sebesar 1.09, dan $\mathrm{P}_{3}$ sebesar 1.07. didapat bahwa benefit cost ratio tertinggi adalah pada perlakuan $\mathrm{P}_{0}$ sebesar 1.10 dan diikuti dengan perlakuan $\mathrm{P}_{2}$ sebesar 1.09 dan $\mathrm{P}_{1}$ sebesar 1.08 dan terkecil pada perlakuan $\mathrm{P}_{3}$ sebesar 1.07. Dari hasil rataan benefit cost ratio yang didapat maka pemanfaatan kulit buah kakao yang difermentasi dengan cairan rumen sampai level 30\% masih dapat dianggap memiliki kelayakan usaha karena nilai benefit cost ratio pada semua perlakuan lebih besar dari 1. Seperti yang dinyatakan kadariah (1987) yang menyatakan bahwa untuk mengetahui tingkat efisiensi suatu usaha dapat digunakan parameter tingkat keuntungan dan kerugian suatu usaha yaitu dengan mengukur besarnya pemasukan dibagi dengan besarnya pengeluaran dimana bila benefit cost ratio $>1$ berarti efisien, benefit cost ratio $=1$ berarti impasdan benefit cost ratio $<1$ berarti tidak efisien.

Rataan Break even point (BEP) yang terdiri dari BEP harga produksi pada perlakuan $\mathrm{P}_{0}$ sebesar Rp. 23.016,-, perlakuan $\mathrm{P}_{1}$ sebesar Rp. 23.233,-, $\mathrm{P}_{2}$ sebesar 23.175,-, dan $\mathrm{P}_{3}$ sebesar Rp. 23.375,-. Didapat bahwa ratan BEP harga produksi tertinggi pada perlakuan $\mathrm{P}_{3}$ sebesar $\mathrm{Rp}$. 23.375. dan yang terendah pada perlakuan $\mathrm{P}_{0}$ sebesar Rp. 23.016,- dimana pada BEP harga produksi pada semua perlakuan dengan memakai kulit buah kakao fermentasi cairan rumen sampai level 30\% masih dalam level aman karena BEP harga produksi masih dibawah tingkat petani yaitu sebesar Rp. 25.000,-. Hal ini sesuai dengan pernyataan cahyono (2002) yang menyatakan bahwa BEP harga produksi menggambarkan harga terendah dari produk yang dihasilkan. Apabila harga ditingkat petani lebih rendah dari harga BEP, maka usaha tani akan mengalami kerugian, dan begitu juga sebaliknya. Selanjutnya BEP volume produksi pada perlakuan $\mathrm{P}_{0}$ sebesar $234 \mathrm{~kg}$, perlakuan $\mathrm{P}_{1}$ sebesar $241 \mathrm{~kg}$, perlakuan $\mathrm{P}_{2}$ sebesar $239 \mathrm{~kg}$ dan perlakuan $\mathrm{P}_{3}$ sebesar $238 \mathrm{~kg}$. Didapat bahwa rataan BEP volume produksi terbesar pada perlakuan $\mathrm{P}_{2}$ sebesar $239 \mathrm{~kg}$ dan yang terendah pada perlakuan $\mathrm{P}_{0}$ sebesar $234 \mathrm{~kg}$. Dari rataan BEP volume produksi masih berada dibawah rataan bobot badan sapi yang diperoleh pada $\mathrm{P}_{2}$ sebesar $257 \mathrm{~kg}$ dan pada $\mathrm{P}_{0}$ sebesar $253 \mathrm{~kg}$.

Rataan income over feed cost (IOFC) pada perlakuan $\mathrm{P}_{0}$ sebesar Rp. 597.718,-, perlakuan $\mathrm{P}_{1}$ sebesar Rp. 555.027,-, $\mathrm{P}_{2}$ sebesar 576.184,-, dan $\mathrm{P}_{3}$ sebesar Rp. 476.339,-. Didapat bahwa rataan income over feed cost tertinggi pada perlakuan $\mathrm{P}_{0}$ sebesar Rp. 597.718,-. dan yang terendah pada perlakuan $\mathrm{P}_{3}$ sebesar Rp. 476,339,-- Walaupun harga pakan pada perlakuan $\mathrm{P}_{0}$ lebih tinggi dibandingkan dengan harga pakan pada perlakuan $\mathrm{P}_{1}, \mathrm{P}_{2}$, dan $\mathrm{P}_{3}$ tetapi penerimaan 
dari penjualan $\mathrm{P}_{0}$ memiliki selisih lebih besar terhadap biaya pakan terhadap perlakuan $\mathrm{P}_{1}, \mathrm{P}_{2}$, dan $\mathrm{P}_{3}$ sebagaimana pernyataan dari Prawirokusumo (1990) yang menyatakan bahwa IOFC adalah selisih antara pendapatan usaha peternakan terhadap total biaya pakan. Pendapatan ini merupakan perkalian antara nilai produksi peternakan dengan harga jual, sedangkan biaya pakan adalah jumlah biaya yang dikeluarkan untuk menghasilkan ternak tersebut.

Rataan return on investment (ROI) pada perlakuan $\mathrm{P}_{0}$ sebesar $11.80 \%$, perlakuan $\mathrm{P}_{1}$ sebesar 8,37, $\mathrm{P}_{2}$ sebesar 8,66 \%, dan $\mathrm{P}_{3}$ sebesar 7,94\%. Didapat bahwa rataan return on investment tertinggi pada perlakuan $\mathrm{P}_{0}$ sebesar $\mathrm{Rp} .11,80 \%$. dan yang terendah pada perlakuan $\mathrm{P}_{3}$ sebesar Rp. 7,94 \%. Hal ini dikarenakan besarnya tingkat laba yang didapat dibanding dengan biaya produksi / modal sehingga tingkat pengembalian investasi modal semakin cepat hal ini sesuai dengan pernyataan Rahardi dkk., (1993) bahwa ROI digunakan untuk mengetahui tingkat efisiensi dari modal yang telah dikeluarkan. Makin kecil nilai ROI ini, makin tidak efisien penggunaan modal dari usaha tersebut. ROI pada semua perlakuan dalam keadaan aman jika dilihat dari suku bungan pinjaman sebesar $1.04 \%$ perbulan sehingga layak dijadikan suatu usaha. Soekartawi (1993) menyatakan bahwa kelayakan usaha diketahui dengan membandingkan ROI dengan tingkat suku bungan pinjaman. Suatu usaha dikatakan layak apabila ROI lebih besar dari tingkat suku bunga pinjaman dan tidak layak apabila ROI lebih kecil dari tingkat suku bungan pinjaman.

\section{KESIMPULAN}

Berdasarkan hasil penelitian dapat disimpulkan bahwa pakan perlakuan P3 dapat meningkatkan pendapatan peternak dilihat dari nilai laba yang diperoleh sebesar Rp. 426.786,dengan nilai $\mathrm{B} / \mathrm{C}$ ratio yang diperoleh sebesar 1,07 selama satu periode pemeliharaan.

\section{DAFTAR PUSTAKA}

Cahyono, B., 2002. Wortel Teknik Budidaya Analisa Usaha Tani. Kanisius, Yogyakarta. Murtidjo. 1995. Analisa Usaha Beternak Sapi Potong Intensif, Penebar Swadaya, Jakarta Prawirokusumo, S., 1990. Ilmu Gizi Komparatif. BPFE, Yogyakarta.

Rahardi, F., Satyawibawa, I dan R. N. Setyowati, 1993. Agribisnis Peternakan. Penebar Swadaya, Jakarta

Soekartawi, J., L. Dillon, J. B. Hardaker dan A. Soeharjo, 1986. Ilmu Usaha Tani dan Penelitian Untuk Pengembangan Petani Kecil. Universitas indonesia-Press, Jakarta. 